\title{
ASSESSMENT OF GENETIC DIVERSITY BASED ON ISSR MARKERS IN NEOPESTALOTIOPSIS SPECIES COLLECTED FROM GUAVA (PSIDIUM GUAJAVA L.) PLANTS AFFECTED WITH CANKER DISEASE IN PAKISTAN
}

\author{
UL HAQ, I. ${ }^{*}-$ IJAZ, S. ${ }^{2}$ \\ ${ }^{I}$ Department of Plant Pathology, University of Agriculture, University Road \\ Faisalabad, Pakistan
}

${ }^{2}$ Centre of Agricultural Biochemistry and Biotechnology (CABB), University of Agriculture University Road, Faisalabad, Pakistan

*Corresponding author

e-mail: imran_1614@yahoo.com

(Received 23 ${ }^{\text {rd }}$ Apr 2019; accepted 16 ${ }^{\text {th }}$ Jul 2019)

\begin{abstract}
Guava is susceptible to various phytopathogenic fungi that could be associated with canker diseases. In Pakistan, farmer's economy is heavily affected by this devastating disease. One of the several strategies to managing it is to develop canker disease resistant guava varieties. For the complete understanding of the associated pathogen and its detailed characterization are required. In this study, Neopestalotiopsis spp accessions of Fungal Molecular Biology Culture Collection UAF (FMB-CC-UAF) isolated from canker affected guava plants were investigated to find genetic diversity among them based on ISSR markers. Eleven (11) ISSR primers were used to analyze eight (8) Neopestalotiopsis accessions. Genetic variation among these fungal accessions were estimated using unweighted pair group method with arithmetic mean (UPGMA) based genetic diversity analysis and Nei's genetic diversity. Among them FMB-Guv-JF2 and FMB-Guv-JF7 showed $13.01 \%$ genetic difference to each other. However, the maximum genetic distance was estimated to be $82.32 \%$ between FMB-Guv-B2A and FMB-Guv-B1. Generated dendrogram revealed the grouping of investigated fungal accessions into distinct clusters with considerable genetic diversity. It is also supported by principal coordinate analysis (PCoA) which showed dispersed pattern of these fungal accessions indicating diverse genetic base.
\end{abstract}

Keywords: fruit crop, plant pathogen, biodiversity, characterization

\section{Introduction}

Guava (Psidium guajava L.) originating from tropical America belongs to the genus Psidium, family Myrtaceae. Its cultivars vary in size and vigor but it's usually a small tree or shrub having 3 to $10 \mathrm{~m}$ height with shallow root system, (Malo and Campbell, 1994; Yadava, 1996; Gutiérrez et al., 2008). Guava is now cultivated in many tropical and subtropical countries worldwide. Guava has potential to grow in a variety of soils having different textures, wide $\mathrm{pH}$ range (usually 4.4-9.4), drainage, even in poor soil and can tolerate dry and humid climatic conditions (Keith et al., 2006). Guava fruits have spherical to pear shape with penetrating aroma. The fruit is a great source of nutrition having vitamin A, C, B complex, iron, calcium, and phosphorus (Pachanawan et al., 2008). Pakistan ranks fourth among guava producers in the world after India, China and Thailand. In Pakistan guava is at third position in terms of area while at fourth position in terms of production (Pervaiz et al., 2008). In Pakistan guava is cultivated on 665 thousand ha with yield $31.79 \mathrm{t} / \mathrm{ha}$ (FAO, 2011), annual production is reduced from 509 to 495 thousand tons during 2015-2016 (Pakistan Bureau of Statistics, 2016). Actual yield is less than potential yields as (10-12 t/ha) (Ul-Haq et al., 2013). 
Worldwide growth and production of Guava is stressed by different biotic and abiotic factors. Among the biotic factors diseases are the major production constraint of Guava. So far, 177 pathogens found to be associated with different plant parts of guava. Out of these 167 are fungal pathogens. In Pakistan twenty-one fungal pathogens have been reported so far, which to infect guava plant (Abbas et al., 2016). Twenty-one (21) fungi have been reported to infect guava plants in Pakistan Phytopthora parasitica, Capnodium sp., Glomerella cingulate, Alternaria alternate, Alternaria tenuissima, Cladosporium, Curvularia sp., Fusarium solani, Fusarium solani f. f. sp. Psidii, Fusarium oxysporum, Fusarium oxysporum f. f. sp. Psidi, Penicillium sp. on tree bark in Pattoki and Sharqpur, Pestalotiopsis brevista, Phoma psidii, Diplodia psidii, Stagnopsis psidii, Pestalotia psidii, Lasiodiplodia undulate, Botryodiplodia theobromae, Polyporus sp. Among the important fungal destructive diseases of Guava in Pakistan, Anthracnose, Wilt, Dieback/decline, fruit canker and scab are of great importance.

While conducting to document the data regarding disease incidence and severity of Guava Anthracnose, dieback and fruit canker and sampling for to detect the association of fungal pathogens with the disease affected plants, the research team of "Fungal Molecular Biology Laboratory" Department of Plant pathology, University of agriculture Faisalabad, Pakistan has identified different isolates as Neopestalotiopsis associated with guava plants. However, evolution results in continuous changes to genetic background of phytopathogens, which ultimately brings new races from them elite cultivars have become susceptible (Malathi et al., 2010). Therefore, unequivocal characterization of newly emerged pathogens is crucial for disease control (Saksena et al., 2013). ISSR marker based genetic analysis for determining and assessing the genetic variation among fungal isolates has become more reliable and efficient approach. Therefore, in this study, genetic diversity among Neopestalotiopsis species accessions of Fungal Molecular Biology Laboratory Culture Collection University of agriculture Faisalabad, Pakistan (FMB-CC-UAF), collected from canker affected guava plants were investigated using ISSR markers.

\section{Materials and methods}

\section{Fungal accessions}

Eight accessions of Neopestalotiopsis species (Table 1) isolated from canker infected branches, leaves and fruits of guava plants were used in this study. These fungal isolates were collected from different regions of Pakistan. Pure culture of each isolate were made by single spore technique and were maintained on Potato Dextrose Agar (PDA) medium. However, the list of potential pathogens associated to guava canker disease is given in the Table 2.

Table 1. Detail of Neopestalotiopsis spp. accessions of guava plant collected from different regions of Pakistan for genetic diversity analysis

\begin{tabular}{c|c|c}
\hline Sr. \# & Isolate code & Strain number \\
\hline 1 & FMB-Guv-B3 & FMB0026 \\
2 & FMB-Guv-C4 & FMB0027 \\
3 & FMB-Guv-MB & FMB0028 \\
4 & FMB-Guv-JF2 & FMB0127 \\
5 & FMB-Guv-JF7 & FMB0128 \\
6 & FMB-Guv-L2A & FMB0129 \\
7 & FMB-Guv-B2A & FMB0130 \\
8 & FMB-Guv-B1 & FMB0013 \\
\hline
\end{tabular}


Table 2. Fungal pathogen(s) associated with Psidium guajava

\begin{tabular}{|c|c|c|c|c|c|}
\hline $\begin{array}{l}\text { Sr. } \\
\text { No. }\end{array}$ & Pathogen & Symptom(s) & Reference & Country & Disease \\
\hline 1 & \begin{tabular}{|c|}
$\begin{array}{c}\text { Fusarium solani f. } \\
\text { f. sp. Psidii }\end{array}$ \\
\end{tabular} & $\begin{array}{l}\text { Chlorosis, wilting of branches and twigs, } \\
\text { browning of internal tissues }\end{array}$ & \begin{tabular}{|c|} 
Bokhari et al., 2008 and \\
Gupta et al., 2010,
\end{tabular} & $\begin{array}{l}\text { Pakistan, } \\
\text { India }\end{array}$ & Wilt, decline \\
\hline 2 & \begin{tabular}{|} 
Fusarium \\
oxysporum f. sp. \\
Psidii
\end{tabular} & \begin{tabular}{|c|} 
Infected seedlings wilt and die at seedling \\
stage, Older plants show vein clearing, leaf \\
epinasty, yellowing of lower leaves, stunting \\
and defoliation. In case of severe decline quick \\
wilting of leaves giving out burning appearance
\end{tabular} & $\begin{array}{c}\text { Prasad et al., 1952; } \\
\text { Pandey and Dwivedi, } \\
\text { 1985; Ansar et al., 1994 } \\
\text { and } \\
\text { Lim and Manicom, 2003 }\end{array}$ & \begin{tabular}{|} 
India, \\
Australia, \\
Pakistan \\
\end{tabular} & Wilt, decline \\
\hline 3 & \begin{tabular}{|c|}
$\begin{array}{c}\text { Phytophthora } \\
\text { parasitica }\end{array}$ \\
\end{tabular} & Reported to be associated with guava & Safdar et al., 2015 & Pakistan & -------------- \\
\hline 4 & Curvularia lunata & Reported to be associated with guava & Safdar et al., 2015 & Pakistan & \begin{tabular}{|l}
--------------- \\
\end{tabular} \\
\hline 5 & $\begin{array}{l}\text { Glomerella } \\
\text { cingulate/ } \\
\text { Colletotrichum } \\
\text { gloeosporioide/ }\end{array}$ & $\begin{array}{c}\text { Twigs began to die back, twig blight, formation } \\
\text { of brown which turns silvery grey on lateral } \\
\text { stages, wither tip, bark splitting and roots } \\
\text { began to rot at basal region }\end{array}$ & $\begin{array}{l}\text { Ansar et al., 1994; } \\
\text { Tandon and Agarwal, } \\
\text { 1954; Lim and } \\
\text { Manicom, } 2003 \text { and ul } \\
\text { haq et al., } 2013\end{array}$ & $\begin{array}{l}\text { All guava } \\
\text { growing } \\
\text { regions }\end{array}$ & $\begin{array}{l}\text { Wilt, dieback } \\
\text { and Decline }\end{array}$ \\
\hline 6 & $\begin{array}{l}\text { Pestalotiopsis } \\
\text { psidii/ Pestalotia } \\
\text { psidii }\end{array}$ & $\begin{array}{c}\text { Symptoms appeared as small necrotic spots of } \\
\text { blackish gray and brittle usually appeared on } \\
\text { leaf apices. Formation of brown spots and } \\
\text { corky lesions on fruit epidermis with elevated } \\
\text { margin }\end{array}$ & $\begin{array}{l}\text { Lim and Manicom, } \\
\text { 2003; Misra and } \\
\text { Prakash, } 1986 \text { and } \\
\text { Rahman et al., } 2003\end{array}$ & \begin{tabular}{|c|} 
Australia, \\
India. \\
Burma, \\
Malaysia, \\
Venezuela, \\
Zambia. \\
Bangladesh \\
\end{tabular} & $\begin{array}{l}\text { Fruit canker } \\
\text { and scab }\end{array}$ \\
\hline 7 & $\begin{array}{l}\text { Gloeosporium } \\
\text { psidii/ } \\
\text { Colletotrichum } \\
\text { gloeosporioides }\end{array}$ & $\begin{array}{c}\text { Numerous small, water soaked and shallow } \\
\text { lesions are produced on ripened fruits, later on } \\
\text { these lesions become enlarged and dispersed } \\
\text { and fuse with each other to form larger spots } \\
\text { which are irregular in shape }\end{array}$ & $\begin{array}{l}\text { Srivastava and Tandon, } \\
1969 \mathrm{a}\end{array}$ & India & $\begin{array}{l}\text { Anthracnose } \\
\text { or Fruit rot }\end{array}$ \\
\hline 8 & $\begin{array}{l}\text { Botryodiplodia } \\
\text { theobromae }\end{array}$ & $\begin{array}{l}\text { Infection starts as brown discoloration that } \\
\text { usually begins at the stem end and moves } \\
\text { downwards in irregular way }\end{array}$ & $\begin{array}{l}\text { Srivastava and Tandon, } \\
1969 \mathrm{~b}\end{array}$ & India & $\begin{array}{l}\text { Soft watery } \\
\text { rot }\end{array}$ \\
\hline 9 & $\begin{array}{l}\text { Aspergillus } \\
\text { awamori, A. } \\
\text { wentii and A } \\
\quad \text { niger }\end{array}$ & $\begin{array}{l}\text { Formation of small sized, round water soaked } \\
\text { spots, rotted portion ooze that gives out } \\
\text { fermented smell, fruit shrinks and reduction in } \\
\text { fruit size occur and blackish mass cover the } \\
\text { whole fruit surface } \\
\end{array}$ & $\begin{array}{l}\text { (Gupta et al., } 1979 \text { and } \\
\text { Lal et al., } 1980\end{array}$ & India & $\begin{array}{l}\text { Aspergillus } \\
\text { soft rot }\end{array}$ \\
\hline 10 & $\begin{array}{l}\text { Pestalotia psidii/ } \\
\text { Pestalotiopsis } \\
\text { psidii }\end{array}$ & $\begin{array}{l}\text { Dark brown to grey colored spots appeared on } \\
\text { leaf margins or tips. On the upper surface of } \\
\text { leaves fruiting pustules may also develops }\end{array}$ & $\begin{array}{l}\text { Bilgrami and Purohit } \\
1971\end{array}$ & India & Leaf spot \\
\hline 11 & Puccnia psidii & $\begin{array}{c}\text { Formation of rust pustules on leaves, shoots, } \\
\text { flower and fruits }\end{array}$ & Misra, 2004 & Brazil & Guava rust \\
\hline 12 & $\begin{array}{l}\text { Rhizopus } \\
\text { stolonifer }\end{array}$ & $\begin{array}{c}\text { On infected fruits develop oily and water } \\
\text { soaked lesions that are slightly sunken with } \\
\text { distinct lesion margins }\end{array}$ & Ooka, 1980 & Hawaii & $\begin{array}{l}\text { Rhizopus } \\
\text { fruit rot }\end{array}$ \\
\hline 13 & Mucor haemalis & \begin{tabular}{|c|} 
Development of water soaked lesions on \\
infected portion, yellow and fuzzy mass of the \\
fungus may cover the whole fruit surface and \\
finally rotted fruits give off yeast like smell \\
\end{tabular} & Kunimoto et al., 1977 & India & $\begin{array}{l}\text { Mucor fruit } \\
\text { rot }\end{array}$ \\
\hline 13 & Rhizoctonia solani & $\begin{array}{c}\text { Water soaked discoloration of infected seeds as } \\
\text { well as seedlings during pre-emergence stage. } \\
\text { During post emergence upper leaves develops } \\
\text { yellow to brown color, move downward and } \\
\text { cause rotting. Finally, seedlings hands down } \\
\text { and eventually die }\end{array}$ & Gupta, 1978 & India & $\begin{array}{l}\text { Damping off } \\
\text { of seedlings/ } \\
\text { seedling } \\
\text { blight }\end{array}$ \\
\hline 14 & $\begin{array}{l}\text { Curvularia } \\
\text { siddiquii }\end{array}$ & $\begin{array}{c}\text { Leaves develop dark brown spots that are } \\
\text { restricted to leaf tips and margins at initial } \\
\text { stage that covers the whole leaf and eventually } \\
\text { defoliate }\end{array}$ & Srivastava, 1963. & India & Leaf spot \\
\hline 15 & $\begin{array}{l}\text { Phytophthora } \\
\text { parasitica/ } \\
\text { Phytophthora } \\
\text { citricola/ } \\
\text { Phytophthora } \\
\text { anicotianae }\end{array}$ & $\begin{array}{c}\text { Infected portion develops greyish brown, water } \\
\text { soaked lesions with a greyish black centre, } \\
\text { internal fruit surface becomes soft that emits } \\
\text { unpleasant smell }\end{array}$ & $\begin{array}{l}\text { Mitra 1929; Gupta et al., } \\
1978 \text { and Ko et al.,1982 }\end{array}$ & & $\begin{array}{l}\text { Phytophthora } \\
\text { fruit rot }\end{array}$ \\
\hline
\end{tabular}




\begin{tabular}{c|c|c|c|c|c}
\hline $\begin{array}{c}\text { Sr. } \\
\text { No. }\end{array}$ & Pathogen & Symptom(s) & Reference & Country & Disease \\
\hline 16 & $\begin{array}{c}\text { Alternaria } \\
\text { tenuissima }\end{array}$ & Reported to be associated with guava & Abbas et al., 2016 & Pakistan & ------------ \\
\hline 17 & B. theobromae & $\begin{array}{c}\text { Yellowing of leaves, wilting and complete } \\
\text { defoliation, infected trees bears no fruits or few } \\
\text { fruits, fruits may become dry and wrinkled }\end{array}$ & Safdar et al., 2015 & Pakistan & $\begin{array}{c}\text { Guava } \\
\text { decline }\end{array}$ \\
\hline 18 & $\begin{array}{c}\text { Small circular spots having dark brown center } \\
\text { with reddish margin. In advance stage of the } \\
\text { disease these spots enlarge and coalesce } \\
\text { causing necrotic patches and blighted } \\
\text { appearance }\end{array}$ & Sridhar and Ullasa, 1978 & India & Leaf blight \\
\hline 19 & $\begin{array}{c}\text { Phomopsis } \\
\text { destructum }\end{array}$ & $\begin{array}{c}\text { Formation of small lesions of dark brown color } \\
\text { and increase to 2 cm diameter. Infected tissues } \\
\text { become soft and entire fruit becomes rotted } \\
\text { within few days }\end{array}$ & Rao et al., 1976 & India & $\begin{array}{c}\text { Phomopsis } \\
\text { rot }\end{array}$ \\
\hline
\end{tabular}

\section{Genomic DNA isolation}

Genomic DNA of these studied fungal accessions was extracted from the mycelia grown on PDA media. Mycelium was ground in liquid nitrogen to turn into fine powder. The fine powder of each sample was treated by CTAB method with some modifications, for genomic DNA isolation. The quality and quantity of extracted DNA was analyzed using agarose gel electrophoresis and spectrophotometer (8000 Spectrophotometer, Thermoscientific.) respectively. Purified DNA of each sample was stored at $4^{\circ} \mathrm{C}$ for further analysis.

\section{PCR analysis}

PCR analysis was performed in 96 well Veriti $^{\mathrm{TM}}$ thermalcycler (Applied Biosystem). For genetic analysis of Neopestalotiopsis spp accessions, eleven (11) ISSR primers (Table 3) were used. PCR for ISSR was carried out in $25 \mu 1$ reaction tubes containing primers, dNTPs, 10X Taq PCR buffer, Taq polymerase and genomic DNA. PCR products were separated on $2 \%$ high resolution agarose (ACTGene), visualized under Gel documentation System (BioRad) and photographs were saved.

Table 3. List of ISSR primers and statistical data obtained by ISSR primers among Neopestalotiopsis spp accessions

\begin{tabular}{|c|c|c|c|c|c|c|c|c|}
\hline Sr.\# & $\begin{array}{l}\text { Primer } \\
\text { code }\end{array}$ & $\begin{array}{c}\text { Sequence (5'- } \\
\left.3^{\prime}\right)\end{array}$ & $\begin{array}{l}\text { Total } \\
\text { Loci }\end{array}$ & $\underset{\text { Loci }}{\text { Monomorphic }}$ & $\begin{array}{c}\text { Polymorphic } \\
\text { Loci }\end{array}$ & $\begin{array}{c}\text { percent } \\
\text { polymorphism }\end{array}$ & \begin{tabular}{|c|c|} 
number of bands \\
or alleles \\
produced per \\
primer
\end{tabular} & PIC \\
\hline 1 & ISSR807 & $(\mathrm{AG})_{8} \mathrm{~T}$ & 6 & 2 & 4 & 66.7 & 30 & 1.3037 \\
\hline 2 & ISSR823 & $(\mathrm{TC})_{8} \mathrm{C}$ & 5 & 0 & 5 & 100 & 22 & 1.7021 \\
\hline 3 & ISSR830 & $(\mathrm{TG})_{8} \mathrm{G}$ & 4 & 2 & 2 & 50 & 21 & 0.6635 \\
\hline 4 & ISSR845 & $(\mathrm{CT})_{8} \mathrm{RG}$ & 5 & 1 & 4 & 80 & 19 & 1.3432 \\
\hline 5 & ISSR848 & $(\mathrm{CA})_{8} \mathrm{RG}$ & 4 & 1 & 3 & 75 & 19 & 0.8745 \\
\hline 6 & ISSR857 & $(\mathrm{AC})_{8} \mathrm{YG}$ & 3 & 0 & 3 & 100 & 13 & 1.1088 \\
\hline 7 & ISSR860 & $(\mathrm{TG})_{8} \mathrm{RA}$ & 3 & 0 & 3 & 100 & 10 & 0.9287 \\
\hline 8 & ISSR4 & $(\mathrm{AGC})_{5} \mathrm{GC}$ & 3 & 0 & 3 & 100 & 13 & 0.8745 \\
\hline 9 & ISSR12 & $(\mathrm{GT})_{8}$ & 3 & 0 & 3 & 100 & 11 & 1.1088 \\
\hline 10 & ISSR15 & $(\mathrm{GT})_{7} \mathrm{AT}$ & 3 & 0 & 3 & 100 & 14 & 0.8583 \\
\hline 11 & ISSR19 & GC (AG)7A & 2 & 1 & 1 & 50 & 15 & 0.1948 \\
\hline Total & & & 41 & 7 & 34 & $-\cdots$ & 187 & ---- \\
\hline Average & & & ---- & ---- & ---- & ---- & ---- & 0.996445 \\
\hline
\end{tabular}




\section{Data analysis}

DNA bands were counted from DNA banding profiles of each ISSR primer and scored as, "1" for presence and " 0 " for absence. The data were analyzed using different software packages such as; PAST v.3.16 for dendrogram based on unweighted pair group method with arithmetic mean (UPGMA) algorithm, PopGen32 v. 1.32 for similarity matrix, DARwin6 v. 6.0 software for Principal Coordinate analysis (PCoA), Power marker v. 3.25 for computing polymorphic information content (PIC).

\section{Results}

DNA markers are used to assess genetic variability among different individuals. This study was carried out with eight different neopestalotiopsis spp accessions to detect genetic variation among them. PCR amplification using eleven (11) ISSR primers yielded total 41 scorable loci of which 7 were monomorphic loci (Table 2). The number of scorable loci varied from 2 (ISSR19) to 6 (ISSR807). However, maximum number of alleles or bands (30) was obtained from primer ISSR807, while only 10 bands or alleles were produced by ISSR860. Of these 11 (eleven) ISSR markers, six primers (ISSR823, ISSR857, ISSR860, ISSR4, ISSR12, ISSR15) showed 100\% polymorphism. The highest value of polymorphic information content (PIC) was 1.7021 of primer ISSR823, whereas the lowest value 0.1948 was from primer ISSR 19 with average PIC value per primer was 0.996445 .

The dendrogram clearly indicated the two clusters, of which cluster I comprising of four fungal accession, FMB-Guv-B3, FMB-Guv-MB, FMB-Guv-C4 and FMB-Guv-B1. However, cluster II was possessing four accessions viz., FMB-Guv-JF2, FMB-Guv-JF7, FMB-Guv-L2A and FMB-Guv-B2A (Fig. 1). This dendrogram showed that these all accessions are diverse and distinct to each other. The fungal accession FMB-Guv-B2A was shown to be highly diverse to FMB-Guv-B1 by scoring the 0.8232 that revealed they are $82.32 \%$ dissimilar followed by FMB-Guv-C4 to whom FMB-Guv-B2A is $76.91 \%$ dissimilar (Table 4). While fungal accessions FMB-Guv-JF2 and FMB-GuvJF7 are closely related as compared to others with similarity co-efficient 0.1301 , which showed, they have $13.01 \%$ dissimilarity, so they are more close to each other. Principal Co-ordinate analysis (PCoA) showed comparable results that were obtained in UPGMA based dendrogram (Fig. 2) and indicating considerable genetic variability among Neopestalotiopsis spp accessions. Principal coordinate analysis (PCoA) also indicated dispersed pattern of these fungal accessions demonstrating diverse genetic base.

\section{Discussion}

Studies at the genomic level are necessary and crucial to understand population genetics and genetic diversity and relationships among individual. There is no report for molecular marker assisted characterization of species of Neopestalotiopsis genus. Therefore, in this study, we have attempted the characterization of different isolates of Neopestalotiopsis spp collected from canker affected guava plants using ISSR molecular marker. Fungal Molecular Biology Culture Collection, University of Agriculture Faisalabad Pakistan, has accessioned these Neopestalotiopsis spp isolates. For identification of polymorphism in terms of genetic diversity among these studied fungal isolates, ISSR markers were used to assess intrapopulation genetic variation in 
Neopestalotiopsis spp accessions collected from different region of Pakistan. The inherent genetic variation in this study on Neopestalotiopsis spp isolates revealed their genetic distinctness unambiguously. Dendrogram based on UPGMA, Nei's original measures and principal Coordinate analysis (PCoA) showed that they all are genetically diverse. These markers yielded percent polymorphism ranged from 50\% to $100 \%$, which is in accordance to the findings of Patel et al. (2018). In this study average polymorphic information content (PIC) values was 0.996445 that indicating the discriminating power and potential of these selected ISSR primers to determine genetic diversity among these fungal accessions. This finding is also similar to the findings of Ijaz et al. (2018 and 2019) and Patel et al. (2018).
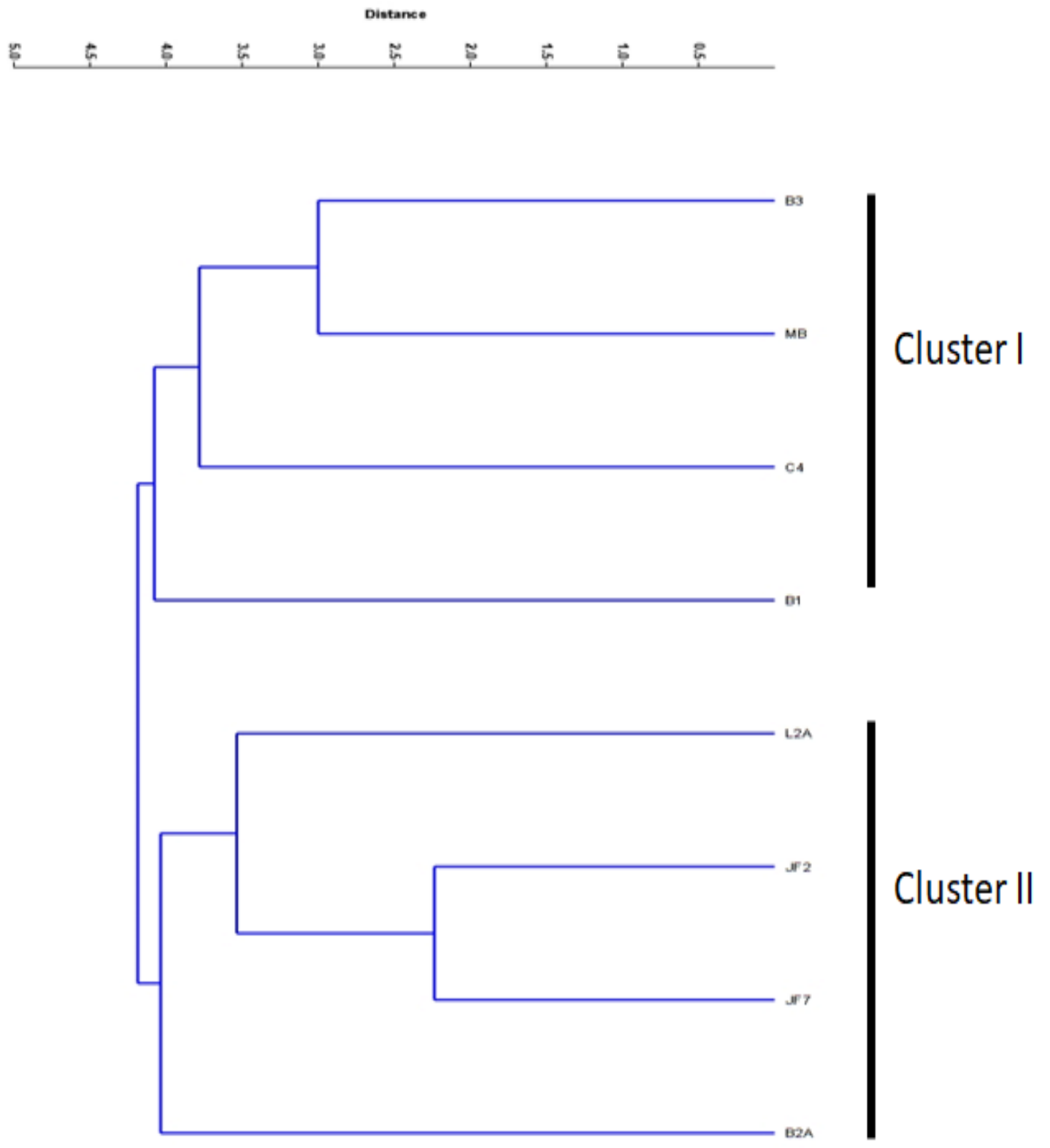

Figure 1. Unweighted Pair Group Method with Arithmetic Mean (UPGMA) based dendrogram of eight Neopestalotiopsis spp accessions collected from canker affected guava plants 
Table 4. Similarity Matrix table based on Nei's original measures: Nei's genetic identity (above diagonal) and genetic distance (below diagonal)

\begin{tabular}{c|cccccccc}
\hline Pop ID & B2A & L2A & JF2 & JF7 & B3 & MB & C4 \\
\hline B2A & $* * * *$ & 0.6098 & 0.5366 & 0.6585 & 0.6585 & 0.6341 & 0.4634 \\
L2A & 0.4947 & $* * * *$ & 0.6829 & 0.7073 & 0.6098 & 0.5366 & 0.6098 & 0.4390 \\
JF2 & 0.6225 & 0.3814 & $* * * *$ & 0.8780 & 0.5366 & 0.6098 & 0.6829 & 0.5610 \\
JF7 & 0.4177 & 0.3463 & 0.1301 & $* * * *$ & 0.4634 & 0.5854 & 0.6098 & 0.5854 \\
B3 & 0.4177 & 0.4947 & 0.6225 & 0.7691 & $* * * *$ & 0.7805 & 0.5610 & 0.5366 \\
MB & 0.4555 & 0.6225 & 0.4947 & 0.5355 & 0.2478 & $* * * *$ & 0.7317 & 0.6098 \\
C4 & 0.7691 & 0.4947 & 0.3814 & 0.4947 & 0.5781 & 0.3124 & $* * * *$ & 0.6341 \\
B1 & 0.8232 & 0.6225 & 0.5781 & 0.5355 & 0.6225 & 0.4947 & 0.4555 & $* * * *$ \\
\hline
\end{tabular}

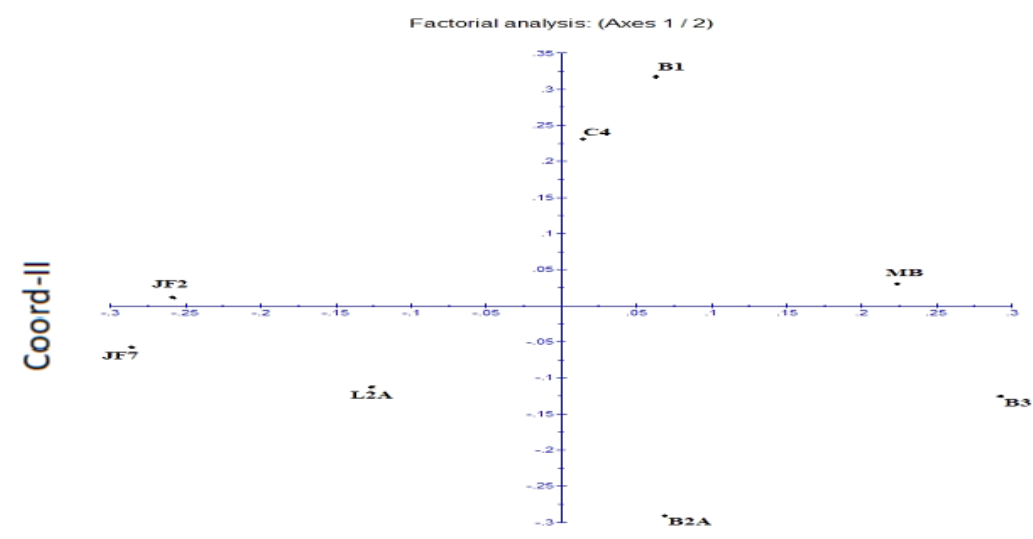

Coord-I

Figure 2. Two-dimensional plot of eight Neopestalotiopsis spp accessions collected from canker affected guava plants using Principal Coordinate analysis (PCoA)

\section{Conclusions}

This research study was based on the investigation of neopestalotiopsis species collected from canker affected guava tree. By considering these fungal isolates belonging to neopestalotiopsis species, to be an associated pathogen of canker disease in guava. We determined their genetic diversity. The genetic diversity analysis revealed that these subjects are of diverse in their genetic background, though, FMB-Guv-JF2 and FMB-Guv-JF7 showed close relatedness to each other. These results suggested that FMB-Guv-JF2 and FMB-Guv-JF7 could be as monophyletic group in phylogenetic hierarchy. However, remaining isolates were shown as genetically diverse background. The maximum genetic diversity was observed between FMB-Guv-B2A and FMB-GuvB1 neopestalotiopsis species fungal accessions. Further experimentation to undertaking their molecular taxonomy would be an imperative step to resolve the species boundaries of theses studied isolates.

\section{REFERENCES}

[1] Abbas, S. Q., Niaz, M., Iftakhar, T., Perveen, A., Abbas, A., Riaz, S. (2016): New Fungal Records on Guava (Psidium guajava) from Pakistan. - Pakistan Academy of Sciences, p.121. 
[2] Ansar, M., Saleem, A., Iqbal, A. (1994): Cause and control of guava decline in the Punjab (Pakistan). - Pakistan Journal of Phytopathology 6(1): 41-44.

[3] Bilgrami, K. S., Purohit, D. K. (1971): New pathogenic species of Pestalotia. - Indian phytopathology 24: 211-213.

[4] Bokhari, A. A., Sahi, S. T., Khan, M. A., Ahmad, R., Din, I. U. (2008): In vitro studies on the biological and chemical control of guava decline caused by different soil borne pathogens. - Pak. J. Agri. Sci. 45: 54-56.

[5] F.A.O. (2011): Food and Agriculture Organization of the United Nations statistical databases. - Accessible online at: http://faostat. fao. org.

[6] Gupta, J. H. (1978): Damping off, a new disease of guava. - Indian Journal of Mycology and Plant Pathology 8: 224.

[7] Gupta, P. C., Madaan, R. L., Suhag, L. S. (1978): Varietal reaction of guava fruits to Phytophthora nicotianae var. parasitica [India]. - Indian Journal of Mycology and Plant Pathology.

[8] Gupta, V. K., Misra, A. K., Gaur, R. K., Jain, P. K., Gaur, D., Sharma, S. (2010): Current status of Fusarium wilt disease of guava (Psidium guajava L.) in India. - Biotechnology 9(2): 176-195.

[9] Gupta, Y. K., Roy, A. N., Yadav, S., Gupta, M. N. (1980): Investigations on post-harvest diseases of guava fruits [India]. - Indian Phytopathology.

[10] Gutiérrez, R. M. P., Mitchell, S., Solis, R. V. (2008): Psidium guajava: a review of its traditional uses, phytochemistry and pharmacology. - Journal of ethnopharmacology 117(1): 1-27.

[11] Ijaz, S., Razzaq, H. A., Babar, M., Haq, I. (2018): Assessment of population genetics of shisham (Dalbergia sissoo) based on genetic structure and diversity analysis. International Journal of Biosciences 13(3): 209-222.

[12] Ijaz, S., Ul Haq, I., Razzaq, H. A., Nasir, B., Babar, M. (2019): ISSR-based population genetics study for tagging a diverse population of shisham (Dalbergia sissoo) in Pakistan. - Applied Ecology and Environmental Research 17(3): 5851-586.

[13] Keith, L. M., Velasquez, M. E., Zee, F. T. (2006): Identification and characterization of Pestalotiopsis spp. causing scab disease of guava, Psidium guajava, in Hawaii. - Plant Disease 90(1): 16-23.

[14] Ko, W. H., Kunimoto, R. K., Nishijima, W. T. (1982): Fruit rot of guava caused by Phytophthora citricola [Psidium guajava, Hawaii]. - Plant Diseases.

[15] Kunimoto, R. K., Ito, P. J., Ko, W. H. (1977): Mucor rot of guava fruits caused by Mucor hiemalis. - Tropical Agriculture 54(2): 185-187.

[16] Lal, B., Rai, R. N., Arya, A., Tewari, D. K. (1980): A new soft rot of guava. - National Academy Science Letters 3(9): 259-260.

[17] Lim, T. K., Manicomz, B. Q. (2003): 12 Diseases of Guava. - Diseases of Tropical Fruit Crops 275.

[18] Lim, T. K., Manicom, B. A. (2003): Diseases of guava. - In: Ploetz, R. C. (ed.) Diseases of tropical fruit crops. pp. 275-289. Pub. CABI, Wallingford, U.K.

[19] Malathi, P., Viswanathan, R., Sundar, A. R., Prakasam, N., Padmanaban, P., Jothi, R., Devi, S. R., Poongothai, M. (2010): Variability among Colletotrichum falcatum pathotypes used for screening red rot resistance in sugarcane. - Sugar Cane International 28(2): 47-52.

[20] Malo, S. E., Campbell, C. W. (1994): The Guava. IFAS Extension. - Bulletin, University of Florida, USA.

[21] Misra, A. K. (2004): Guava diseases - their symptoms, causes and management. - In: Diseases of Fruits and Vegetables: Volume II (pp. 81-119). Springer, Dordrecht.

[22] Misra, A. K., Prakash, O. (1987): Studies on diseases of fruit crops. - Annual Report, CIHNP, Lucknow, pp.124-125. 
[23] Mitra, M. (1929): Phytophthora parasitica dast. Causing 'damping off' disease of cotton seedlingsand 'fruit-rot' of Guava in India. - Transactions of the British Mycological Society 14(3-4): 249-254.

[24] Ooka, J. J. (1980): Guava fruit rot caused by Rhizopus stolonifer in Hawaii. - Plant Disease 64(4): 412-413.

[25] Pachanawan, A., Phumkhachorn, P., Rattanachaikunsopon, P. (2008): Potential of Psidium guajava supplemented fish diets in controlling Aeromonas hydrophila infection in tilapia (Oreochromis niloticus). - Journal of bioscience and bioengineering 106(5): 419-424.

[26] Pandey, R. R., Dwivedi, R. S. (1985): Fusarium oxysporum f. sp. psidii as a pathogen causing wilt of guava in Varanasi district, India. - Journal of Phytopathology 114(3): 243-248.

[27] Pandey, R. R., Dwivedi, R. S. (1985): Fusarium oxysporum f. sp. psidii as a pathogen causing wilt of guava in Varanasi district, India. - Phytopathologische Z. 114: 243-248.

[28] Patel, P., Rajkumar, B. K., Parmar, P., Shah, R., Krishnamurthy, R. (2018): Assessment of genetic diversity in Colletotrichum falcatum Went accessions based on RAPD and ISSR markers. - Journal of Genetic Engineering and Biotechnology 16(1): 153-159.

[29] Pervaiz, U., Khan, A., Javed, R., Zeb, J. (2008): Production constraints of guava in district Kohat. - Sarhad J. Agric 24(3): 549-554.

[30] Prasad, N., Mehta, P. R., Lal, S. B. (1952): Fusarium wilt of guava (Psidium guyava L.) in Uttar Pradesh, India. - Nature 169(4305): 753.

[31] Rahman, M. A., Ansari, T. H., Meah, M. B., Yoshida, T. (2003): Prevalence and pathogenicity of guava anthracnose with special emphasis on varietal reaction. - Pak $\mathbf{J}$ Bio Sci 6(3): 234-241.

[32] Rao, D. P. C., Agarwal, S. C. (1976): Efficacy of antibiotics against Phomopsis destructum causing fruit rot of guava. - Hindustan Antibiotic Bulletin 18: 108-110.

[33] Safdar, A., Khan, S. A., Safdar, M. A. (2015): Pathogenic association and management of Botryodiplodia theobromae in guava orchards at Sheikhupura district, Pakistan. International Journal of Agriculture and Biology 17(2).

[34] Saksena, P., Vishwakarma, S. K., Tiwari, A. K., Singh, A., Kumar, A. (2013): Pathological and molecular variation in Colletotrichum falcatum went isolates causing red rot of sugarcane in the Northwest Zone of India. - Journal of plant protection research 53(1): 37-41.

[35] Sridhar, T. S., Ullasa, B. A. (1978): Leaf blight of guava-a new record. - Current Science 47(12).

[36] Srivastava, H. P. (1963): Some leaf spot fungi. - Proceedings of the National Academy of Sciences 34(3): 188-198.

[37] Srivastava, M. P., Tandon, R. N. (1969b): Studies on Botryodiplodia rot of guava. Indian Forest Rec NS Forest Pathol.

[38] Srivastava, M. P., Tandon, R. N. (1969a): Postharvest diseases of Guava in India. - Plant Disease Reporter 53(3): 206-208.

[39] Tandon, R. N., Agarwala, R. K. (1954): Pathological studies ofGlœosporium psidii causing die-back of guavas. - Proceedings: Plant Sciences 40(4): 102-109.

[40] Ul-Haq, I. M. S., Khan, S. A., Jaskani, M. J., Ullah, Z. (2013): Occurrence of guava anthracnose in Punjab (Pakistan) and its integrated management. - Pak. J. Agri. Sci 50(4): 707-710.

[41] Yadava, U. L. (1996): Guava production in Georgia under cold-protection structure. Progress in new crops. ASHS Press, Arlington, VA, 451-457. 